\title{
Phytochemical and Antifungal Activity of Anthraquinones and Root and Leaf Extracts of Coccoloba mollis on Phytopathogens
}

\author{
Iuri Bezerra de Barros ${ }^{1}$, Juliana Feijó de Souza Daniel ${ }^{1 *}$, Jurandir Pereira Pinto ${ }^{1}$, Maria \\ Inês Rezende ${ }^{2}$, Raimundo Braz Filho ${ }^{3}$ and Dalva Trevisan Ferreira ${ }^{1}$ \\ ${ }^{I}$ Departamento de Química; Universidade Estadual de Londrina; Londrina - PR - Brasil. ${ }^{2}$ Departamento de \\ Bioquímica e Biotecnologia; Universidade Estadual de Londrina; Londrina - PR - Brasil. ${ }^{3}$ Laboratório de Ciências \\ Químicas; Centro de Ciência e Tecnologia; Universidade Estadual do Norte Fluminense; Campos - RJ - Brasil
}

\begin{abstract}
The aim of this work was to study the phytochemical and antifungal activity of anthraquinones and root and leaf extracts of Coccoloba mollis on phytopathogens. The chemical analysis of ethanolic extracts showed a mixture of long-chain hydrocarbons, carboxyl esters and 3-taraxerone in the leaf extract. Two anthraquinones (emodin and physcion) were isolated and identified from the root extract. Phytochemical screening using the pharmacognostic methods revealed the presence of flavonoids and tannins in the leaves and roots. Anthraquinones were only found in the root extract, no alkaloids, coumarins, saponins and simple phenolics were present. The antifungal activity of C. mollis extracts and anthraquinones isolated from the root of this plant against Botryospheria ribis, B. rhodina, Lasiodiplodia theobromae and Fusarium sp showed promising results for their use as fungicides, where emodin was the most active compound, which inhibited the microorganisms tested up to $44 \%$.
\end{abstract}

Key words: Antifungal; Phytochemical; Lasiodiplodia; Botryosphaeria; Coccoloba mollis

\section{INTRODUCTION}

Lasiodiplodia theobromae, the anamorphic form of Botryosphaeria rhodina (Barbosa et al., 2007), causes serious crop damages in Brazil. This fungus is a cosmopolitan microorganism with a worldwide distribution in the tropics and subtropics, and shows a range of more than 500 known hosts (Freire et al., 2004; Punithalingam, 1980). This pathogen can cause different symptoms in infected plants, including die-back, cankers on the branches, stems and roots, and lesions in the stalks, leaves, fruits and seeds, besides causing the death of seedlings and grafts. Its capacity to infect the fruits places it among the most aggressive pathogens for the seeds, causing post-harvest problems (Maftoonazad et al., 2007). Many of these plants and fruits are of major commercial importance in developing countries. One report describes $L$. theobromae as the cause of keratomycosis and discusses risk factors and clinical features of fungal keratitis in order to improve the prognosis with earlier treatment (Donnio et al., 2006). Another report described a

*Author for correspondence: julianasouza@uel.br 
patient with $L$. theobromae pneumonia, who died 14 days after the cadaveric liver transplantation (Woo et al., 2008).

Botryosphaeria is a fungus that generally attacks the plants with weaknesses caused by other factors such as insect damage, drought stress, harsh winters, etc. It is known that these problems occur in over 100 genera and the symptoms can vary depending on the type of plant and the extent of infection. Generally, Botryosphaeria causes cankers which start as soft depressions below the bark and grow oval-shaped with callous tissue around the edges (Barbosa et al., 2007, Taylor et al., 2009). Fusarium sp. is a filamentous fungus widely distributed in the plants and in soil. It is found in the normal mycoflora of commodities, such as rice, beans, soybeans, and other crops. While most species are more common in tropical and subtropical areas, some inhabit soil in cold climates (Berrocal-Lobo and Molina, 2007). Coccoloba ssp. [Polygonaceae] is commonly used in Brazil as an astringent, in the treatment of fever, diarrhea, menstrual problems, gonorrhea, hemorrhoids and uterine hemorrhage (Corrêa and Penna, 1969). C. mollis, known popularly as "novateiro," "novato," "pajaú" or "madeira-jaú," displays a wide geographical distribution, occurring in Costa Rica, Panama, Colombia, Venezuela, Surinam, French Guiana, Ecuador, Bolivia and Brazil (Melo, 2004). There are few published studies of this plant in the scientific literature. Hexane extracts of stem, bark and leaves of $C$. mollis have demonstrated larvicidal activity against Aedes aegypti, showing potential in the control of this vector of tropical diseases (Oliveira et al., 2010). In another study testing the ethanolic extracts of the leaves and roots of $C$. mollis, the results showed that both extracts induced the DNA damage at a concentration of $20 \mu \mathrm{g} / \mathrm{mL}$, but neither showed genotoxicity at any of the concentrations tested, based on the micronucleus test (Tsuboy et al., 2007). In the present work, the phytochemical and antifungal activity of anthraquinones [emodin, physcion], and root and leaf extracts of $C$. mollis were determined on $L$. theobromae, B. ribis, B. rhodina and Fusarium sp.

\section{MATERIALS AND METHODS}

\section{Plant Material}

Leaves and roots of $C$. mollis were collected in Natingui and Briolândia, districts of Ortigueira,
Paraná on December 15, 2007. Dr. Ana Odete Santos Vieira performed the botanical identification. A voucher specimen No BARROS, I.B. 001 has been deposited in the Herbarium of the Universidade Estadual de Londrina-UELParaná, Brazil.

\section{Phytochemical}

The dried and powdered materials (leaves and roots) of $C$. mollis were extracted with $95 \%$ ethanol at room temperature, and the solvent was removed under vacuum to yield $40 \mathrm{~g}$ of root extract and $85 \mathrm{~g}$ of leaf extract. The leaf extract was submitted to successive partition with ethyl acetate and the fractions $(30 \mathrm{~g})$ were chromatographed on a silica gel (174 g) column using solvents with increasing polarity (n-hexane, dichloromethane, ethyl acetate). Fractions 1-19 and 21-29 were eluted with hexane and purified by recrystallization in $\mathrm{MeOH}$, yielding two white compounds. Fractions 96-135 were eluted in hexane and purified using the preparative thinlayer chromatography, which resulted in a white compound. The root extract was submitted to successive partition with n-hexane and ethyl acetate. The hexane soluble fraction $(4.5 \mathrm{~g})$ was chromatographed on a silica gel (164 g) column using solvents with increasing polarity (n-hexane, dichloromethane, ethyl acetate). Fractions 270-310 (CMR-3) were eluted in hexane and purified by recrystallization in $\mathrm{MeOH}$; the fractions 15011505 (CMR-4) were eluted in dichloromethane: $10 \%$ ethyl acetate and purified by acid-base extraction, with both fractions yielding orange compounds.

\section{Antifungal activity \\ Microorganisms}

L. theobromae was isolated from Annona squamosa (pine cone) (Barbosa et al., 2007), $B$. ribis was isolated from Eucalyptus citriodora, $B$. rhodina was obtained from a stem canker on a eucalyptus tree (Barbosa et al., 1996), and Fusarium sp. was obtained from the contaminated animal feed (Universidade Estadual de LondrinaUEL).

\section{Test for antifungal activity}

In vitro biological activity of the ethanolic extracts was assessed based on radial hyphal growth rate in the presence and absence of the extracts. The samples were dissolved in DMSO. The concentrations analyzed were $1.25,1.88$ and 3.75 
$\mathrm{mg} \mathrm{mL} \mathrm{m}^{-1}$ of each extract and isolated compounds. Aliquots $(0.8 \mathrm{~mL})$ of the each sample were added to assay the flasks containing $17 \mathrm{~mL}$ of sterile growth medium (PDA). After vortexing, $17.8 \mathrm{~mL}$ were poured into Petri dishes $(70 \times 15 \mathrm{~mm})$. The controls used were: Control-I $=$ plates containing only PDA, Control-II = plates treated with DMSO $(0.8 \mathrm{~mL})$ and Control-III = plates containing the fungicide Captan [4-cyclohexene-1,2dicarboximide, $\mathrm{N}$ - (trichloromethyl)thiol] ( 0.18 $\%$ ). The assay was performed by placing a $0.7 \mathrm{~cm}$ diameter plug of growing mycelium in the center of a Petri dish. Three replicates were run simultaneously (Quiroga et al., 2001). In all the plates, the radial mycelia growth was measured after 7-10 days, the time required for the microorganisms to grow in the culture medium containing only PDA at $28 \pm 2{ }^{\circ} \mathrm{C}$. Each data point represented the mean of at least four measurements of a growing colony (MGC: mycelial growth in control; MGS: mycelial growth in the samples). Percent growth inhibition was calculated as:

$\%$ grow inhibition $=\frac{\text { MGC }- \text { MGS }}{\text { MCG }} \times 100$

\section{General procedures}

${ }^{1} \mathrm{H}-\mathrm{NMR}(400 \mathrm{MHz})$ and ${ }^{13} \mathrm{C}-\mathrm{NMR}(100 \mathrm{MHz})$ spectra were recorded on a Bruker DRX- 500 Spectrometer using $\mathrm{CDCl}_{3}$ and tetramethylsilane as the internal standard. IR spectra were obtained with a Shimadzu FTIR Model 8300 6AD, using $\mathrm{KBr}$ pellets. GC/MS-capillary gas chromatography was performed in a Shimadzu GC-17A chromatography coupled to a Shimadzu GC/MSQP5000 using a DB-1 capillary column (cc, $30 \mathrm{~m}$ $\mathrm{x} 0.25 \mathrm{~mm}$ ), with temperature programmed at $60{ }^{\circ} \mathrm{C}$ for $4 \mathrm{~min}$ over a range of $60-250{ }^{\circ} \mathrm{C}$ at $10{ }^{\circ} \mathrm{C} / \mathrm{min}$, and $250-330^{\circ} \mathrm{C}$ at $20^{\circ} \mathrm{C} / \mathrm{min}$.

\section{Statistical analysis}

All the experiments were conducted in triplicate. The data were evaluated by the statistical analysis (ANOVA) to determine the level of significance of differences $(p<0.05)$. A pairwise comparison of each treatment was applied using Tukey's multiple range comparison test to identify the significant differences between results of the fungal bioassays. Statistical data analysis was carried out using the software Statistica 7.1 (STATISTICA, 2006).

\section{RESULTS AND DISCUSSION}

Pharmacognostic methods are used to obtain a general evaluation of the chemical composition of a plant, to give an indication of the important groups of secondary metabolites present (Costa, 2001). Phytochemical screening using pharmacognostic methods revealed the presence of anthraquinones only in the roots, and flavonoids and tannins in leaves and roots, and no alkaloids, coumarins, saponins and simple phenolics were found. The compounds isolated and the classes of metabolites detected were compatible with the records found in the literature for this genus. The major compounds in the extracts identified by the spectroscopic methods $\left[\left(\mathrm{NMR},{ }^{1} \mathrm{H} /{ }^{13} \mathrm{C}\right.\right.$, CG-MS and IR) and by comparison with those described in the literature] (Chu et al., 2005; Basu et al., 2005) were a mixture of long-chain hydrocarbons (fraction 1-19), carboxyl esters (fraction 21-29) and 3-taraxerone (fraction 96-135, Fig 1) from the ethanolic leaf extract and two anthraquinones, emodin and physcion, (CMR-3, CMR-4, Fig. 1 and Table 1) from the root extract.

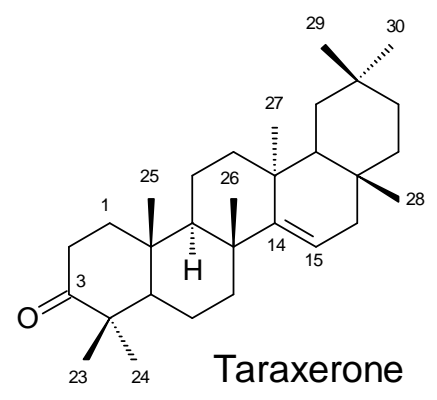<smiles>Cc1cc(O)c2c(c1)C(=O)c1cc(O)cc(O)c1C2=O</smiles>

Emodin<smiles>COc1cc(O)c2c(c1)C(=O)c1cc(C)cc(O)c1C2=O</smiles>

Physcion

Figure 1 - Structure of taraxerone, emodin and phiscion. 
Table 1 - Spectral data for CMR-3, CMR-4 $\left({ }^{1} \mathrm{H}: 500 \mathrm{MHz} ;{ }^{13} \mathrm{C}: 125 \mathrm{MHz}\right.$; in $\left.\mathrm{CDCl}_{3}\right)$ compared with the physcion and emodin references (Chu et al., 2005). Chemical shifts in $\delta$ (ppm).

\begin{tabular}{ccccccccc}
\hline & \multicolumn{2}{c}{ physcion } & \multicolumn{2}{c}{ CMR-3 } & \multicolumn{2}{c}{ emodin } & \multicolumn{2}{c}{ CMR-4 } \\
\cline { 2 - 8 } & $\delta_{\mathrm{H}}$ & $\delta_{\mathrm{C}}$ & $\delta_{\mathrm{H}}$ & $\delta_{\mathrm{C}}$ & $\delta_{\mathrm{H}}$ & $\delta_{\mathrm{C}}$ & $\delta_{\mathrm{H}}$ & $\delta_{\mathrm{C}}$ \\
\hline $\mathrm{C}_{1}$ & 12,06 & 166,1 & 12,01 & 166,92 & 11,96 & 164,6 & 11,96 & 166,44 \\
$\mathrm{C}_{2}$ & 6,74 & 106,1 & 6,62 & 107,30 & 6,56 & 107,9 & 6,54 & 108,17 \\
$\mathrm{C}_{3}$ & & 161,9 & & 162,48 & & 161.4 & & 162,14 \\
$\mathrm{C}_{4}$ & 7,32 & 107,8 & 7,21 & 108,47 & 7,11 & 108.8 & 7,10 & 109.36 \\
$\mathrm{C}_{5}$ & 7,64 & 124,0 & 7,57 & 124,84 & 7,42 & 124,0 & 7,40 & 124,51 \\
$\mathrm{C}_{6}$ & & 148,0 & & 149,13 & & 148,2 & & 148,76 \\
$\mathrm{C}_{7}$ & 7,09 & 120,7 & 6,89 & 121,10 & 7,07 & 120,4 & 7,10 & 121,23 \\
$\mathrm{C}_{8}$ & 12,19 & 164,7 & 12,21 & 164,81 & 12,04 & 164,4 & 12,06 & 166,17 \\
$\mathrm{C}_{9}$ & & 190,2 & & 190,76 & & 189,6 & & 190,43 \\
$\mathrm{C}_{10}$ & & 181,6 & & 182,11 & & 181,2 & & 181,34 \\
$\mathrm{C}_{4 a}$ & & 134,7 & & 135,82 & & 135,0 & & 135,47 \\
$\mathrm{C}_{8 \mathrm{a}}$ & & 113,1 & & 114,32 & & 113,3 & & 113,90 \\
$\mathrm{C}_{9 \mathrm{a}}$ & & 110,2 & & 110,34 & & 108,7 & & 109,36 \\
$\mathrm{C}_{10 \mathrm{a}}$ & & 132,7 & & 133,25 & & 132,7 & & \\
$\mathrm{O}-\mathrm{Me}$ & 3,92 & 55,7 & 3,95 & 57,09 & & & & \\
$\mathrm{Me}$ & 2,42 & 21,7 & 2,51 & 22,44 & 2,38 & 21,5 & 2,38 & \\
\hline
\end{tabular}

Phytopathogens, such as $B$. ribis, $B$. rhodina, $L$. theobromae and species of Fusarium, are controlled by intensive fungicide applications which may have resulted in the development of resistant populations, detriment to human health and contamination of the environment. Due to these consequences, several studies on the use of plant extracts, essential oils and metabolites against these fungal species have been reported in the literature. Aqueous, methanol and hexane extracts of fifteen Mexican plants species showed activity against Fusarium oxysporum f. sp. gladioli (Pizaña et al., 2010). The ethanolic extract of Jatropha curcas seed cake showed antifungal activities against important fungal phytopathogens: Fusarium oxysporum, Pythium aphanidermatum, Lasiodiplodia theobromae, Curvularia lunata, Fusarium semitectum, Colletotrichum capsici and Colletotrichum gloeosporioides (Donlaporn and Suntornsu, 2010). Essential oils of Ocimum gratissimum inhibited the growth of Aspergillus niger, Penicillium chrysogenum, Alternaria sp., Botryosphaeria rhodina and Rhizoctonia sp. (Faria et al., 2006). Ocimum basilicum and Cymbopogon nardus oils displayed fungicidal activity against Colletotrichum musae and Fusarium proliferatum (Anthony et al., 2002), while Cinnamomum zeylanicum (L.) and Syzygium aromaticum (L.) Merr oils had fungistatic and fungicidal effects against anthracnose pathogens isolated from banana: Fusarium proliferatum and
Colletotrichum musae (Ranasinghe et al., 2002). The results in the present work supplemented the studies described above and showed the great potential of Brazilian plants in the discovery and development of fungicides.

As shown in Table 2 and Figure 2, Control-II was used in the calculation of $\%$ growth inhibition, where the fungi tested grew satisfactorily. The presence of the fungicide Captan (Control III) in the culture medium inhibited $B$. ribis growth completely, while $B$. rhodina, $L$. theobromae and Fusarium sp showed 60.5, 49.4 and $48.3 \%$ growth inhibition, respectively. Statistical evaluations of colony diameter showed that $C$. mollis root extract and emodin did not differ significantly at the 5\% level $(\mathrm{p}=0.993)$ with regard to percent growth inhibition for L. theobromae (33.2\% and $31.6 \%$, respectively). In the case of $B$. ribis, there was no statistically significant difference $(\mathrm{p}=0.332)$ between $C$. mollis leaf extract $(14.4 \%)$ and physcion $(16.7 \%)$. B. rhodina results did not show significant differences for $C$. mollis root extract $(43.5 \%)$ versus emodin $(43.7 \%)(\mathrm{p}=0.999)$ and for C. mollis leaf extract (34.9\%) versus physcion $(36.1 \%)(\mathrm{p}=0.993)$. The leaf and root extracts tested on Fusarium sp showed significant differences. C. mollis root extract and emodin showed a greater percent growth inhibition for $L$. theobrome, B. ribis and B. rhodina. These results were in agreement with the presence of emodin in C. mollis root and its known microbial activity. 
Table 2 - Antifungal activity of emodin, physcion, and root and leaf extracts of Coccoloba mollis against phytopathogenic fungi.

\begin{tabular}{|c|c|c|c|c|c|c|c|c|}
\hline \multirow[b]{2}{*}{ Samples } & \multicolumn{2}{|c|}{ L. theobromae } & \multicolumn{2}{|c|}{ B. ribis } & \multicolumn{2}{|c|}{ B. rhodina } & \multicolumn{2}{|c|}{ Fusarium sp } \\
\hline & $\begin{array}{c}\text { AMGD } \\
(\mathbf{c m})\end{array}$ & $\begin{array}{c}\% \\
\text { Inhibition }\end{array}$ & $\begin{array}{c}\text { AMGD } \\
(\mathbf{c m})\end{array}$ & $\begin{array}{c}\% \\
\text { Inhibition }\end{array}$ & $\begin{array}{c}\text { AMGD } \\
(\mathbf{c m})\end{array}$ & $\begin{array}{c}\% \\
\text { Inhibition }\end{array}$ & $\begin{array}{c}\text { AMGD } \\
(\mathbf{c m})\end{array}$ & $\begin{array}{c}\% \\
\text { Inhibition }\end{array}$ \\
\hline Control-II & 6.3 & & 5.0 & & 6.3 & & 4.8 & \\
\hline Control-III & 3.2 & 49.4 & 0.0 & 100 & 2.5 & 60.5 & 2.48 & 48.3 \\
\hline $\begin{array}{c}\text { Emodin } \\
1.25 \mathrm{mg} \cdot \mathrm{mL}^{-1}\end{array}$ & 4.3 & 31.6 & 3.5 & 30.3 & 3.5 & 43.7 & ND & ND \\
\hline $\begin{array}{c}\text { Physcion } \\
1.25 \mathrm{mg} \cdot \mathrm{mL}^{-1}\end{array}$ & 5.6 & 11.7 & 4.2 & 16.7 & 4.0 & 36.1 & ND & ND \\
\hline $\begin{array}{l}\text { Leaf extract } \\
3.75 \mathrm{mg} \cdot \mathrm{mL}^{-1}\end{array}$ & 6.9 & 0 & 4.3 & 14.4 & 4.1 & 34.9 & & \\
\hline $\begin{array}{l}\text { Root extract } \\
3.75 \mathrm{mg} \cdot \mathrm{mL}^{-1}\end{array}$ & 4.2 & 33.2 & 4.0 & 21.1 & 3.5 & 43.5 & & \\
\hline $\begin{array}{l}\text { Leaf extract } \\
1.88 \mathrm{mg} . \mathrm{mL}^{-1}\end{array}$ & & & & & & & 4.2 & 12.7 \\
\hline $\begin{array}{l}\text { Root extract } \\
1.88 \mathrm{mg} . \mathrm{mL}^{-1}\end{array}$ & & & & & & & 3.6 & 24.3 \\
\hline
\end{tabular}

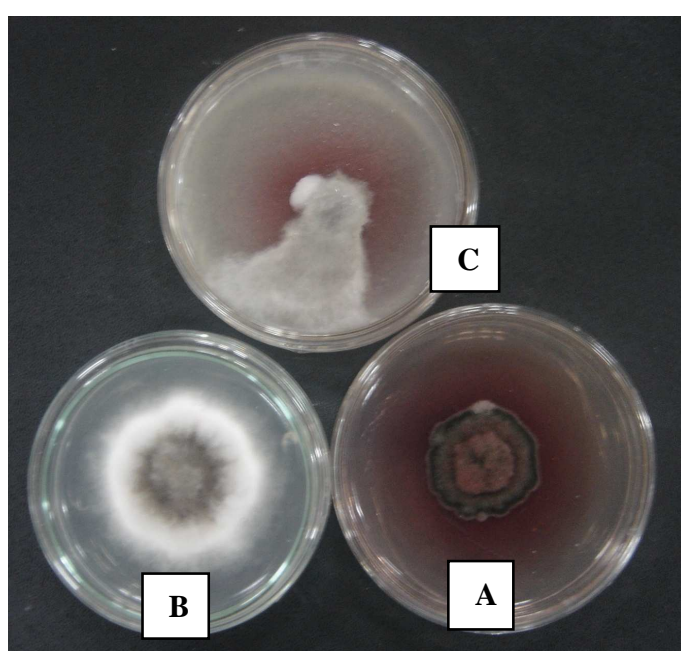

Figure 2 - Antifungal activity of root extracts of C. molis against Botryospheria rhodina (A); Control-II (B); Fungicide Captan (C).

There have already been many reports about the antibacterial and antifungal activities of anthraquinones isolated from the natural sources. Emodin was also found to be an efficient antifungal agent. Species of plants of the family Polygonaceae: Polygonum (rhizome, root, stem), Rheum (rhizome, leaf) and Rumex (root, seed, leaf, stem, flower) contain emodin (Izhaki, 2002). Rhein, physcion, aloe-emodin and chrysophanol isolated from Rheum emodi rhizomes exhibited antifungal activity against Candida albicans,
Cryptococcus neoformans, Trichophyton mentagrophytes and Aspergillus fumigatus (Agarwal et al., 2000). Emodin and physcion isolated from Ventilago madraspatana showed antibacterial activity against three Bacillus sp. (Basu, et al., 2005). Emodin isolated from Rhamnus triquetra bark was highly effective against spore germination in the 17 fungal species tested, including seven species of Alternaria and three species of Fusarium (Singh et al., 1992).Studies on antifungal and antibacterial 
activities of the extracts and metabolites of species of the genus Coccoloba have been reported. An ethanolic extract and fractions of Coccoloba acrostichoides aerial parts were active against bacteria and fungi, and the triterpene betulin inhibited the growth of Fusarium oxysporum (Cota et al., 2003). The antifungal activity of the (-)Epigallocatechin Gallate isolated that Coccoloba dugandiana were reported. (Li et al., 1999)

In the present work, the extracts of $C$. mollis leave and roots showed antifungal activities against important fungal phytopathogens. The antifungal activity of $C$. mollis could be due to the presence of long chain hydrocarbons, carboxyl esters and taraxerone and of other metabolites isolated from the ethanol extract of the leaves and stems of $C$. mollis Casar, such as simiarenol (pentacyclic triterpene), one diterpene and two phytosteroids (Oliveira et al., 2008).

The results suggested that the antifungal activity correlated with the presence of triterpenes, such as taraxerone. This activity could be due to a change in membrane permeability arising from the membrane lipid alteration (Haraguchi et al., 1999). The statistical comparison of the results on the antifungal activity of emodin, physcion and $C$. molis root extract against $B$. ribis versus $B$. rhodina yielded $\mathrm{p}$ values of $0.338,0.571$ and 1.00 , respectively. Botryospheria species compared with $L$. theobrome using $C$. mollis root extract showed no significant difference $(\mathrm{p}=0.674)$; however, when anthraquinones (emodin and physcion) was used, a significant difference was observed ( $\mathrm{p}<$ 0.05 ). Only the anthraquinones with $L$. theobrome showed a significant difference when compared with the Botryospheria species. Compared with the corresponding data for Botryospheria sp. $(\mathrm{p}=0.252)$, Fusarium $\mathrm{sp}$. versus $B$. rhodina ( $\mathrm{p}=0.647)$ and Fusarium versus B. ribis showed produced similar results, although the leaf extract concentration tested for the Fusarium evaluation was lower. The results demonstrated the fungicidal potential of the extracts.

\section{CONCLUSIONS}

Since the ethanolic extracts of the leaves and roots of $C$. mollis showed no genotoxicity with the micronucleus test, the antifungal activity of the extracts (roots and leaves) and anthraquinones (emodin and phycion) of $C$. mollis, shown in the present study, could be considered promising for the control of species of Lasidiodiplodia, Botryosphaeria and Fusarium. Thus, the search for new fungicidal substances from $C$. mollis with low residual effects on the environment could be of importance for agriculture.

\section{AKNOWLEDGMENTS}

Authors thank the Coordenação de Aperfeiçoamento de Pessoal de Nível Superior CAPES for scholarship to Iuri B. de Barros.

\section{REFERENCES}

Agarwal, S. K.; Singh, S. S.; Verma, S. and Kumar, S. (2000), Antifungal activity of anthraquinone derivatives from Rheum emodi. J. Ethnopharmacol., 72, 43-46.

Anthony, S.; Abeywickrama, K.; Dayananda, R.; Wijeratnam, S. W. and Arambewela, L. (2004), Fungal pathogens associated with banana fruit in Sri Lanka, and their treatment with essential oils. Mycopathologia, 57, 91-97.

Barbosa, A. M.; Dekker, R. F. H. and Hardy, G. E. (1996), Veratryl alcohol as an inducer of laccase by an ascomycete, Botryosphaeria sp., when screened on the polymeric dye Poly R-478. Lett. Appl. Microbiol., 23, 93-96.

Barbosa, A. M.; Saldanha, R. L.; Garcia, J. E.; Dekker, R. F. H. and Vilas-Boas, L. A. (2007), Genetic Diversity Among Botryosphaeria Isolates And Their Correlation With Cell Wall-Lytic Enzyme Production. Braz. J. Microbiol., 38, 259-264.

Basu, S.; Ghosh, A. and Banasri, H. (2005), Evaluation of the Antibacterial Activity of Ventilago madraspatana Gaertn., Rubia cordifolia Linn. and Lantana camara Linn.: Isolation of Emodin and Physcion as Active Antibacterial Agents. Phytother. Res., 19, 888-894.

Berrocal-Lobo, M., and Molina, A. (2008), Arabidopsis defense response against Fusarium oxysporum. Trends Plant Sci., 13, 145-150.

Chu, X.; Sun, A. and Liu, R. (2005), Preparative isolation and purification of five compounds from the Chinese medicinal herb Polygonum cuspidatum Sieb. et Zucc by high-speed counter-current chromatography. J. Chromatogr. A., 1097, 33-39.

Corrêa, M.P., and Penna, L. (1969), Dicionário das plantas úteis do Brasil e das exóticas cultivadas. Rio de Janeiro: Ministério da Agricultura.

Costa, A. F. (2001), In Farmacognosia, Farmacognosia Experimental, Fundação Cal. Golbenkian - Lisboa, Chapters: 10-20. 
Cota, B. B.; de Oliveira, A. B.; de Souza-Filho, J. D. and Braga, F. C. (2003), Antimicrobial activity and constituents of Coccoloba acrostichoides. Fitoterapia, 74, 729-731.

Donnio, A.; Desbois, N.; Boiron, P.; Théodose, R.; Mouniee, D.; Thoumazet, F. and Merle, H. (2006), Mycotic keratitis and endophthalmitis caused by unusual fungi: Lasiodiplodia theobromae. J. Fr. Ophtalmol., 29, 196.

Faria, T. de J.; Ferreira, R. S.; Yassumoto, L.; Souza, J. R. P.; Ishikawa, N. K. and Barbosa, A. de M. (2006), Antifungal Activity of essential oil isolated from Ocimum gratissimum L. (eugenol chemotype) against Phytopathogenic Fungi. Braz. Arch. Biol. Technol., 49, 867-871.

Freire, F. C. O.; Viana, F. M. P.; Cardoso, J. E. and Santos, A. A. (2004), Novos Hospedeiros do Fungo Lasiodiplodia theobromae no Estado do Ceará. Comunicado Técnico on line. Comitê de Publicações Expediente Comunicado Técnico, 91, ISSN 16796535, Fortaleza, CE.

Haraguchi, H.; Kataoka, S.; Okamoto, S.; Hanafi, M. and Shibata, K. (1999), Antimicrobial triterpenes from Ilex integra and the mechanism of antifungal action. Phytother. Res., 13, 151-156.

Izhaki, I. (2002), Emodin - a secondary metabolite with multiple ecological functions in higher plants. New Phytol., 155, 205-217.

Li, X. C.; ElSohly, H. N.; Nimrod, A. C. and Clark, A. M. (1999), Antifungal activity of (-)-Epigallocatechin Gallate from Coccoloba dugandiana. Planta Med., 65, 780.

Maftoonazad, N.; Ramaswamy, H. S.; Moalemiyan, M. and Kushalappa, A. C. (2007), Effect of pectin-based edible emulsion coating on changes in quality of avocado exposed to Lasiodiplodia theobromae infection. Carbohydr. Polym., 68, 341-349.

Melo, E. (2004), The Species of Cocoloba P. Browne (Polygonaceae) from brasilian Amazonia. Acta Amaz., 34, 525-551.

Oliveira, P. E. S.; dos Santos, W. S.; Conserva, L. M. and Lemos, R. P. L. (2008), Constituintes químicos das folhas e do caule de Coccoloba mollis Casaretto (Polygonaceae). Braz. J. Pharmacogn., 18, 713-717.

Oliveira, P. V.; Ferreira, J. C.; Moura, F. S.; Lima, G. S.; de Oliveira, F. M.; Oliveira, P. E. S.; Conserva, L. M.; Giulietti, A. M. and Lemos, R. P. L. (2010), Larvicidal activity of 94 extracts from ten plant species of northeastern of Brazil against Aedes aegypti L. (Diptera: Culicidae). Parasitol. Res., 107, 403-407.
Pizaña, C. G.; Necha, L. L. B. and Gomez, Y. R. (2010), Evaluation of the Fungicidal Activity of Leaves Powders and Extracts of Fifteen Mexican Plants Against Fusarium oxysporum f. sp. gadioli (Massey) Snyder and Hansen. Plant Path. J., 9, 7987.

Punithalingam, E. (1980), Plant diseases attributed to Botryodiplodia theobromae. Vaduz: Pat. J. Cramer, pp. 123.

Quiroga, E. N.; Sampietro, A. R. and Vattuone, M. A. (2001), Screening antifungal activities of selected medicinal plants. J. Ethnopharmacol., 74, 89-96.

Ranasinghe, L.; Jayawardena, B. and Abeywickrama, K. (2002), Fungicidal activity of essential oils of Cinnamomum zeylanicum (L.) and Syzygium aromaticum (L.) Merr et L.M.Perry against crown rot and anthracnose pathogens isolated from banana. Lett. Appl. Microbiol., 35, 208-211.

Saetae, D. and Suntornsuk, W. (2010), Antifungal Activities of Ethanolic Extract from Jatropha curcas Seed Cake. J. Microbiol. Biotechnol., 20, 319-324.

Singh, U. P.; Singh, K. P.; Singh, S. P.; Ram, S. N. and Pandey, V. B. (1992), Effect of emodin isolated from Rhamnus triquetra on spore germination of some fungi. Fitopatol. Bras., 17, 420-422.

Statistica V 7.1 For Windows: Statsoft Inc. Software, Tulsa, OK, 2006.

Taylor, K.; Barber, P. A.; Hardy, G. E. S. J. and Burgess, T. I. (2009), Botryosphaeriaceae from tuart (Eucalyptus gomphocephala) woodland, including descriptions of four new species. Mycol. Res., 113, 337-353.

Tsuboy, M. S.; Marcarini, J. C.; Ferreira, D. T.; Ribeiro, L. R. and Mantovani, M. S. (2007), Citotoxicidade e Genotoxicidade da Espécie Medicinal Coccoloba Mollis Casar. (Polygonaceae). Paper present at Congresso Brasileiro de Mutagênese, Carcinogênese e Teratogênese Ambiental,. Revista Brasileira de Toxicologia. São Paulo: Sociedade Brasileira de Toxicologia,. 21-24 Outubro, Mangaratiba, Brasil.

Woo, P. C. Y.; Lau, S. K. P.; Ngan, A. H. Y.; Tse, H.; Tung, E. T. K. and Yuen, K. Y. (2008), Lasiodiplodia theobromae Pneumonia in a Liver Transplant Recipient. J. Clin. Microbiol., 46, 380-384.

Received: April 28, 2010; Revised: August 12, 2010; Accepted: March 14, 2011 
Página<smiles>[In]</smiles>

Branco 